\title{
Consistency of University Internship Program in the Philippines
}

\author{
Kingie G Micabalo ${ }^{1}$, Ryan D Montilla ${ }^{2}$ and Jesszon B. Cano ${ }^{3}$ \\ ${ }^{1 \& 2}$ University of Cebu, Cebu City, Philippines \\ ${ }^{3}$ Hospitality Management, Bohol Island State University - Candijay, Philippines \\ E-mail: kmicabalo@uc.edu.ph, rmontilla@uc.edu.ph, jesszon.cano@bisu.edu.ph
}

\begin{abstract}
Internship Program is intended to give understudies an occasion to supplement essential learning with handy information, abilities, and alluring mentalities and to pick up hands-on involvement with perceived Host Training Establishment. This investigation assesses the degree of Realization on Internship Program in a University. The investigation respondents were the 247 understudies, utilizing the descriptive method and survey questionnaire on a simple random sampling. Frequency and simple percentage and Mode were used to dissect and decipher the information assembled. The discoveries uncovered that interns Highly Realized the Guidelines for Higher Education Institution, Guidelines for Student Interns, and Guidelines for Host Training Establishment revealed a Realized interpretation on the Guidelines for Student Interns Coordinator/ Adviser. It concluded that the Internship Program should concoct a firmly checked framework and being continued now and again dependent on the necessities caught by the understudies on each separate program. The system used does not guarantee effectiveness, for there should be a comparison between statistical and practical approaches. Personality Development Seminar, Work Ethics, and Sexual Harassment and PreInternship Seminar and Orientation might be executed to upgrade the understudies' information, aptitudes, and estimations to deal with pre-employment status.
\end{abstract}

Keywords: Business, Accountancy, Internship Program, descriptive study, Cebu City, Philippines

\section{INTRODUCTION}

The internship program is intended to furnish understudies with an occasion to supplement formal learning with viable information, abilities, and attractive mentalities and to pick up hands-on involvement with perceived Host Training Establishment (Repaso, 2019). It is as program rules as per Lewis et al. (2009) that come from the HEI (Higher Education Institution), which gauges the adequacy of the current program. It speaks to expansive articulations that join numerous regions of between related information and abilities created over the program's term through a wide scope of courses and encounters. It speaks to a higher perspective, portray wide parts of conduct, and envelop various learning encounters. The rules must cover a dream of "the ideal alumni" of the program and oblige previous objectives. As rivalry for graduate positions builds, understudies need to consider better approaches to separate themselves from the entirety of the other similarly qualified and talented up-and-comers. Graduates who have relevant work environment experience will be more esteemed by businesses, making temporary jobs an alluring possibility.
As expressed above, an Internship is an open door offered by a business to likely representatives, called assistants, to work at a firm for a fixed timeframe. Assistants are normally students or understudies, and most entry-level positions last between a month and three months.

There is a gap in entry-level positions that are normally low maintenance whenever offered during a college semester and full-time whenever offered during the excursion time frames. An entry-level position should give down to earth aptitudes, work environment experience, and more important information on that industry, in return for the business profiting by your work. A temporary position can be either paid or wilful. The pattern is progressively (and appropriately) towards the previous, as deliberate temporary positions are regularly referred to as exploitative. As would expect, entry-level positions that pay well are normally the most serious. It can be extraordinary for understudies since it can truly help build up proof abilities in undertaking the board, critical thinking, and customer relationship with the executives. Regardless of whether the temporary position is just short, it can outfit you with a scope of adaptable aptitudes and help the organization and assemble important associations in the business.

Furthermore, it looks great on the understudy's educational plan vitae. Managers regularly use entry-level positions as a successful method of publicizing the organization's alumni plans to understudies. Reviews demonstrate that practically $50 \%$ of all alumni businesses enlist in any event $20 \%$ of the organization's ex-assistant for preparing plans. Graduates will re-visitation the association that recruited them as an assistant for all-day work in the wake of leaving college. After they graduate, recruiting ex-understudies is favorable for bosses as these alumni comprehend the organization and the occupation they will do. Ex-assistants require less preparation than new competitors, which spares time and assets (Allen, 2013).

By the presented situation, the researchers empowering Business and Management discipline and the Student Internship Program in the Philippines (SIPP) Coordinator will decide on the acknowledgment of the Internship Program to guarantee arrangement saw in partnered company. By the exploration led, the scientist will have the option to suggest a Student Internship Development Plan outfitted to advance consistent improvement. Principally, 
this investigation anticipated the advantage of the University of Cebu Lapu-Lapu and Mandaue grounds, explicitly in the College of Business Administration, to improve and advance the Student Internship Program.

\section{FRAMEWORK}

This investigation is anchored on the Program Theory, which gives a cognizant image of how change happens and how to improve execution. The Program Theory tells the best way to create, speak to, and use program hypothesis mindfully and deliberately to suit a specific circumstance. The necessities appraisal to mediation plan, from usage to results assessment, from strategy detailing to strategy execution and Assessment, program hypothesis is foremost (Funnell, and Rogers, 2011). Program hypothesis as a bunch of unequivocal or certain suppositions by partners about what activity is needed to understand a social, instructive, or medical condition and why the difficult will react to this activity (Chen, 2012).

As indicated by Chen (2012), the motivation behind Program Theory is not just to evaluate whether an intercession works or does not work but also how and why it does. The data is fundamental for partners to improve current or future projects. Program hypothesis is an efficient arrangement of partners' prescriptive suspicions and distinct presumptions basic projects, regardless of whether express or certain. Illustrative presumptions, as per Donaldson (2012), called the change model, manage what causal cycles are relied upon to end up achieving program objectives. Prescriptive suspicions, called the activity model, manage what moves must be made in a program to deliver attractive changes. Program hypothesis utilizes the activity model and change model to address logical factors and arranging, and usage gives that are extraordinarily intrigued to partners. The assertion above is also upheld by Action Model, a deliberate arrangement for orchestrating staff, assets, settings, and backing associations to arrive at an objective gathering and convey program intercession administrations. A program depends on an association to distribute assets, facilitate exercises, and select, train, direct implementers, and other staff (Saunders, 2015).

The Theory of Change likewise strengthens the investigation by Weiss (2019), which itemized extensive depiction and delineation of how and why an ideal change is relied upon to occur in a specific setting. As indicated by Maini et al. (2017), the Outcomes Framework at that point gives the premise to distinguish what sort of movement or mediation will prompt the results recognized as preconditions for accomplishing the drawn-out objective. The exact connection among exercises and the accomplishment of the drawn-out objectives are all the more completely comprehended through this methodology. It prompts better arranging, in that exercises are connected to an itemized comprehension of how change occurs. It likewise prompts better Assessment, as it is conceivable to gauge progress towards accomplishing longer-term objectives that go past the distinguishing proof of program yields. It is additionally supported by Maini et al. (2017), expressing the development of a Theory of Change ordinarily happens through a consultative cycle, expecting partners to consider how projects can achieve change. To Cs help cause express any fundamental suppositions, to recognize the function of setting and give proof to legitimize the chain of causal pathways. The To C cycle had utility in uniting respondents to agree on the intercession systems and its ideal results. It likewise exhibited the significance of applying frameworks thinking approach that helped distinguish and connect all partners who could impact the intercession's achievement. The facilitator's function was vital for guaranteeing partners away from To Cs, moderating any lopsided force characteristics, and empowering a basic, legit, and intelligent methodology.

Frameworks hypothesis of Mead (2019), transforming one piece of the framework ordinarily influences different parts and the entire framework, with unsurprising examples of conduct. For self-learning and self-adjusting frameworks, the positive development and transformation rely on how well the framework is changed with its current circumstance. A few frameworks work for the most part to help different frameworks by supporting the other framework's upkeep to forestall disappointment. In the investigation of Fishman et al. (2007), framework change has arisen as a predominant edge through which nearby state and public funders and experts over a wide cluster of fields approach people's work. It features the significance of profound and evident structures inside a framework, just as the connections and interdependencies among these framework parts. It incorporates taking care of the predominant standardizing, asset, regulative, and operational qualities that direct the conduct and lived encounters of framework individuals.

As per Miller (2017), frameworks have improved both the educators and the understudies' presentation. Using innovation, the school, the executives, and the educators can get information that can guide the best way to improve the understudies' exhibition. The understudy Intern facilitator can evaluate and conduct the understudy to distinguish the regions where the understudy is powerless, which needs upgrade and advancement. By that, instructors can adjust the advancement plan as needs be to improve understudy execution as assistants.

Vroom's Expectancy Theory by Victor Vroom further backs the investigation where the hypothesis accepted that SIPP facilitators are inspired to perform exercises to accomplish some objective to the degree that they expect certain activities that would help them accomplish the objective. The hypothesis depends on the suspicion that a person's conduct results from the decisions made for the elective game-plan, which is identified with the mental occasions happening simultaneously with the conduct. It implies an individual chooses specific conduct over different practices with a desire for getting results; the one wanted for (Sims, 
2002). The arithmetical portrayal of Vroom's Expectancy hypothesis is Valence: It alludes to the worth that an individual puts on a specific result or strength of a person's inclination for the normal compensations of the result. To have a positive valence, one ought to favor accomplishing the result of not achieving it (Weaver, 2016).

It is also upheld by Purvis et al. (2015) that execution prompts rewards, and the prizes offered are alluring. The examination fights that mental and hierarchical atmosphere impact discernments applicable to hope, that thus decide: a) regardless of whether partners will partake in a venture, b) whether they will help or damage the undertaking, and c) whether a partner is spurred to finish these activities. It underpins that partners evaluate the mental atmosphere's bearing and strength and that the appraisals shape inspiration to take an interest in dynamic help, token help, or counter-execution activities. As demonstrated in Kamau's (2015) investigation, inspiration is essential to continue execution levels, particularly among understudy intern facilitators. Bosses need to distinguish what is truly significant in the labor force to guarantee that they effectively cook the necessities. Parts of cash, acknowledgment, profession movement and advancement, management, relational relations, sound correspondence channels arose as key factors that prompted inspiration conduct and impacted great execution conduct. Furthermore, the great working connection between the labor force and the board is huge, and both staff and the business ought to endeavor to keep up good working relations. The two players should cooperate to guarantee that they execute the correct inspiration strategies to profit the organization and workers.

\section{OBJECTIVES OF THE STUDY}

The examination is expected to assess the degree of Realization of the Internship Program. This examination filled in as the reason for the Student Internship Development Plan to guarantee its significance to the understudy Interns. It distinguishes the respondents' profile regarding age, sexual orientation, common status, year graduated, and course major. It likewise looks to recognize the Assessment of Realization in the College of Business and Accountancy Student Internship program.

\section{METHODOLOGY}

\section{A. Research Design}

The investigation utilized the descriptive technique with the poll as the chief instrument in information gathering. The researchers broke down and classified the (CMO) No.104 Series of 2017, generated from CHED, and made a review poll.

\section{B. Research Environment and Respondents}

The examination was directed at the University of Cebu Lapu-Lapu and Mandaue. It offers a Bachelor of Science in
Accountancy, Bachelor of Science in Business Administration, with four majors: Management Accounting, Marketing Management, Financial Management, and Human Resource Development Management. Since the examination was to distinguish the degree of Realization on the College of Business and Accountancy Student Internship program, the area was good for the exploration. The 247 respondents of the examination study were determined through the slovins formula on a simple random sampling. Frequency, simple percentage, and Mode were used to treat the assembled information.

\section{C.Data Gathering}

To accomplish the examination study, these means were followed. Letter of aim routed to the Dean of the College of Business and Accountancy for information gathering, requesting that consent direct the study. The polls were managed through Google structure as the principal instrument. The information was being classified and broke down. A boundary was utilized to decipher the reactions: (1-Not Realized) (2-Less Realized) (3-Realized) (4-Highly Realized).

\section{RESULTS AND DISCUSSION}

This part presents the consequences of the information accumulated. The initial segment presents the respondent's demographic profile. The next part presents the information fair and square of Realization of the Student Internship program.

TABLE 1PROFILE OF THE RESPONDENTS ( $=247)$

\begin{tabular}{|l|c|c|}
\hline & Frequency & Percentage \\
\hline Age & & \\
\hline 19 & 15 & 6.00 \\
\hline 20 & 116 & 47.00 \\
\hline 21 & 37 & 15.00 \\
\hline 22 & 42 & 17.00 \\
\hline 23 and above & 37 & 15.00 \\
\hline Gender & & \\
\hline Male & 37 & 14.89 \\
\hline Female & 210 & 447.26 \\
\hline Civil Status & & \\
\hline Single & 247 & 100.00 \\
\hline Course Major & \\
\hline Management Accounting & 63 & 134.18 \\
\hline Financial Management & 26 & 55.91 \\
\hline Marketing Management & 137 & 290.72 \\
\hline $\begin{array}{l}\text { Human Resource } \\
\text { Development Management }\end{array}$ & 21 & 44.73 \\
\hline
\end{tabular}

Table I shows the College of Business Administration graduates' profile based on age, gender, civil status, and 
course major. It shows that respondents aged 20 years old got the highest equivalent at $47 \%$. This data implies that the graduates of CBA are at the young adult stage. It was further supported by the Education State University (2019), stating that Higher education in the Philippines is strongly in the private sector. Most bachelor's degrees are for four years. Students are usually from 17 to 20 years old. As for gender majority or $58.57 \%$ of the College of Business and Accountancy graduates were female. It shows that the female has more inclination to take the College of Business and Accountancy programs. As for the civil status, most were single or equivalent to $100 \%$. As for the course major, the majority were Marketing Management major with 26\%. It implies that students choose to undergo the program. As per Siu (2017), Marketing and business majors plan understudies better for business insight, investigation, and executives. They figure out how to examine a stock market, section clients, compose promoting plans, create spending plans, and dissect information. Finally, business organization majors may become familiar with the administrative side of the business world. Notwithstanding seminars on advertising basics, they also figure out how to oversee individuals, cycles, and financial plans. Showcasing is an intriguing order regarding space for both imaginative sorts in the plan and Marcom office, just as the logical kinds in the business knowledge and examination office.

\section{TABLE II LEVEL OF REALIZATION ON THE STUDENT INTERNSHIP PROGRAM AS REVEALED BY THE RESPONDENTS}

\begin{tabular}{|l|c|c|c|c|}
\hline $\begin{array}{l}\text { Guidelines for Higher Education Institution } \\
\text { (HEI)- University of Cebu }\end{array}$ & Mode & Interpretation & (\%) & Rank \\
\hline $\begin{array}{l}\text { Guarantees that the understudy executes the } \\
\text { authorized MOA, Internship Contract, and } \\
\text { Endorsement. }\end{array}$ & 4 & $\begin{array}{c}\text { Highly } \\
\text { Realized }\end{array}$ & 63.83 & 1 \\
\hline $\begin{array}{l}\text { Guarantee that the Student Interns will obtain real } \\
\text { and applicable abilities in each learning zone, task, } \\
\text { and exercises timetable. }\end{array}$ & 3 & Realized & 53.19 & 2 \\
\hline $\begin{array}{l}\text { Shield understudy assistants are going through the } \\
\text { temporary job from badgering, abuse, miserable } \\
\text { preparing conditions, and different conditions that } \\
\text { negate or nullify the entry-level position's point. }\end{array}$ & 3 & Realized & 48.94 & 3 \\
\hline $\begin{array}{l}\text { Make sure that all student Interns must acquire } \\
\text { medical certificates before deployment. }\end{array}$ & 3 & Realized & 44.68 & 4 \\
\hline Aggregate Mode & 3 & Realized & & \\
\hline
\end{tabular}

Table II shows the results of the Student Internship Program's level of Realization, as revealed by the respondents. Ensurethat all student Interns must acquire medical certificates before deployment, whichrecorded the lowest Mode and interpreted as Realized.There is still a need for thorough monitoring of the deployment process stating that it should be done before the deployment. As per Pachman (2009), the pre-business clinical Assessment (likewise alluded to as a pre-situation assessment) endeavors to put and keep up representatives in a word related climate adjusted to physiological and mental limits. The pre-work Assessment's objective is to decide if an individual is fit to play out their occupation without danger to himself or others. It is likewise conceptualized inside the Act of word related medication - it is expected that the analyst is needed to have factual information on both working and ailments.

The safeguarding student interns undergoing internship from harassment, exploitation, deplorable training conditions, and other conditions that contravene or defeat the internship purpose also recorded the lowest Mode and interpreted as Realized. It should be done properly, for this includes the student's emotional aspect, contributing more to his/ her holistic being. In the investigation of the Committee on Pediatric Workforce, S. O. (2000), Sexual provocation in the work environment and instructive settings establish a climate that belittles individuals and negatively affects precise execution and adequacy just as authoritative profitability and unit resolve. As affectability to this mindboggling issue has been as of late uplifted, there is much disarray, even about precisely what comprises inappropriate behavior, just about modalities fitting for managing the issue. It is occupant on managers, associations, and organizations to speak to all constituents, male and female, and give instruction and direction to encourage annihilation of this violent conduct.

Ensuring that the student executes the notarized MOA, Internship Contract and Endorsement, and ensuring that the Student Interns will acquire actual and relevant competencies in each learning area, assignments, and schedule of activities recorded the highest Mode and were interpreted as Highly Realized. According to the Commission on Higher Education (2017), CMO 104 s. 2017 which is the Revised Guidelines for Student Internship Program in the Philippines. Memorandum of Agreement (MOA) is an arrangement executed among HEI and accomplices HTEs determining the definite job and duties of every concerned gathering, the security of understudy assistants, preparing the plan, early goals, and technique for Assessment. While the Internship Contract is likewise significant for it contains the name of the gatherings in 
question, objectives, and improvement of explicit aptitudes, the brief portrayal of the extent of the arrangement, key agreements for each gathering included Moreover, the strategic viewpoint must address three perspectives; faculty account and offices, and a detailed execution plan.
Achievements must be set to guarantee that the help level is improved, so the activity plan and victories emerging from the arrangement are continually observed and changed if fundamental (Liew S. et al., 2012).

\section{TABLE III LEVEL OF REALIZATION ON THE STUDENT INTERNSHIP PROGRAM AS REVEALED BY THE RESPONDENTS}

\begin{tabular}{|l|c|c|c|c|}
\hline Guidelines for Student Interns & Mode & Interpretation & (\%) & Rank \\
\hline $\begin{array}{l}\text { Ensures student must submit Journal on a daily, } \\
\text { weekly, monthly basis on time }\end{array}$ & 4 & Highly Realized & 65.96 & 1 \\
\hline $\begin{array}{l}\text { Make sure that the student submits his/ her Job } \\
\text { Evaluation Report and Performance Rating on } \\
\text { time. }\end{array}$ & 4 & Highly Realized & 59.57 & 2 \\
\hline $\begin{array}{l}\text { Ensures that the student is enrolled in B.A. 9 } \\
\text { "On-the-Job Training Program." }\end{array}$ & 4 & Highly Realized & 57.45 & 3 \\
\hline $\begin{array}{l}\text { Guarantees that the understudies present a } \\
\text { clinical declaration that the person in question is } \\
\text { healthy }\end{array}$ & 4 & Highly Realized & 57.45 & 4 \\
\hline $\begin{array}{l}\text { Ensure that students submit a notarized } \\
\text { Internship Contract from their parents/ legal } \\
\text { guardians and MOA on time. }\end{array}$ & 4 & Highly Realized & 57.45 & 4 \\
\hline $\begin{array}{l}\text { Allow the student interns to have a pre- } \\
\text { internship orientation and seminar certificate. }\end{array}$ & 4 & Highly Realized & 55.32 & 5 \\
\hline Submit Certificate of Completion on time & 4 & Highly Realized & 48.94 & 6 \\
\hline Submit Endorsement Letter on time & 3 & Realized & 48.94 & 6 \\
\hline $\begin{array}{l}\text { Submit actual sketch or picture of the Host } \\
\text { Training Establishment }\end{array}$ & 3 & Realized & 44.68 & 7 \\
\hline $\begin{array}{l}\text { Have an evaluation and Assessment of their } \\
\text { experiences and problems encountered. }\end{array}$ & 3 & Realized & 44.68 & 7 \\
\hline $\begin{array}{l}\text { Evaluation and Assessment of their experiences } \\
\text { in the SIPP and tour- of - duty }\end{array}$ & 3 & Realized & 44.68 & 7 \\
\hline Aggregate Mode & 4 & Highly Realized & & \\
\hline
\end{tabular}

Table III shows the data on assessing the level of Realization as perceived by the respondents from the student interns' guidelines. It shows that indicator, as to submit Certificate of Completion on time, got the lowest Mode and interpreted as Realized. It should be properly done for contingency issues. The said requirement is evaluated before the teacher will sign the oath of the student's candidacy, which is about to graduate.

The submission of the actual sketch or picture of the Host Training Establishment and submission of Endorsement Letter on time also got the lowest Mode and interpreted as Realized. The coordinator must identify an important focus on whether to approve and gave the deployment order to the student intern by the existing sketch of the industry's actual photo. It was additionally upheld in which, as per Lozano et al. (2017), representations can be ordered as close to home, mutual, influential, and handover draw. Contingent upon every class and level of vagueness additionally fluctuates.

The evaluation and Assessment of experiences and problems encountered and Assessment of student experiences in the SIPP and tour- of - duty also got the lowest Mode and interpreted as Realized. In the investigation of Fuentealba (2011), Assessment is an incredible learning apparatus that can improve learning and schooling. The cycle of understudy appraisal ought to line up with curricular objectives and instructive destinations. Recognizing the appraisal procedures vital for the correct Assessment of understudies' advancement inside individual projects is as significant as setting up curricular substance and conveyance strategies. The organization, program, or course can make changes to improve the nature of instruction. If appraisal configuration lines up with instructive results and instructional techniques, it improves the nature of training and supports understudy learning.

As for the student is enrolled in B.A. 9 "On-the-Job Training Program." It makes sure that the student submits his/ her Job Evaluation Report and Performance Rating on time, Certificate of Completion. Students submit a medical certificate and make sure that students submit a notarized Internship Contract from parents/ legal guardians and MOA on time got the highest Mode and interpreted as Highly Realized.As indicated, CHED (2017), CMO 104 s. 2017 which is the Revised Guidelines for Student Internship Program in the Philippines. The main necessity of the multitude of terms and conditions is that the understudy probably enlisted the hands-on preparation subject. In any case, the program will not start and consider invalid. 
TABLE IV LEVEL OF REALIZATION ON THE STUDENT INTERNSHIP PROGRAM AS REVEALED BY THE RESPONDENTS

\begin{tabular}{|l|c|c|c|c|}
\hline $\begin{array}{l}\text { Guidelines for Host Training Establishment } \\
\text { (HTE) }\end{array}$ & Mode & Interpretation & (\%) & Rank \\
\hline $\begin{array}{l}\text { Ensures that the LGU, SEC, and DTI duly } \\
\text { authorize the company. }\end{array}$ & 4 & Highly Realized & 55.32 & 1 \\
\hline $\begin{array}{l}\text { Screens the organization upon the issuance of } \\
\text { testaments of fulfillment for the understudy } \\
\text { assistants not later than about fourteen days after } \\
\text { finishing the temporary position. }\end{array}$ & 3 & Realized & 55.32 & 1 \\
\hline $\begin{array}{l}\text { Guarantees urge understudy assistants to build up } \\
\text { their character and polished skill and shield them } \\
\text { from physical or moral peril. }\end{array}$ & 4 & Highly Realized & 51.06 & 2 \\
\hline $\begin{array}{l}\text { Ensures that the company provides adequate and } \\
\text { appropriate materials, facilities, practical training, } \\
\text { and other work-related experiences. }\end{array}$ & 4 & Highly Realized & 48.94 & 3 \\
\hline Aggregate Mode & & Highly Realized & & \\
\hline
\end{tabular}

Table IV shows the data on assessing the level of Realization as perceived by the respondents from the guidelines for the Host Training Establishment (HTE).

It shows that the indicator ensures that the company provides instructions with provisions for adequate and appropriate materials; facilities, practical training, and other work-related experiences got the lowest Mode and interpreted as Realized. Even though it is interpreted as Realized, there is still a need to monitor and evaluate its profile properly.

It was also upheld by Mikkonen et al. (2017), in which direction gives understudy at work environments to relate unequivocally to the exercises.

It opens up occasions for students to partake in aggregate practices by slowly accepting greater accountability and all the more requesting errands in abilities improvement. The student's self-regulative aptitudes, such as obligation and the capacity to step up to the plate, and effectively look for direction, influence how direction is managed in the work network during preparing.

Moreover, these abilities may likewise decide the student's possibilities for creating mastery in future work environments.

As to ensure that the company is duly authorized by the LGU, SEC, and DTI, and ensures that the company encourages student interns to develop personality and professionalism and protect them from physical or moral danger got the highest Mode and interpreted as Highly Realized.

As indicated by the DTI (2010), all administrations are commanded to give administrations' productive conveyance to people by lessening regulatory formality and forestalling joining and defilement and giving punishments thereof.

In compliance with this Act, the public authority set norms for handling licenses to operate, and licenses gave by urban communities and districts pointed toward improving productivity in the business enlistment framework and decreasing the expense of working together in the nation. The indicator monitors the company upon issuing

certificates of completion for the student interns not later than two weeks after completing the internship, which got The highest Mode and was interpreted as Realized.

However, the results state a positive implication of all the areas from the past program interventions. There are still areas that need to be improved and eventually need and intervention throughout the new product implemented by CHED, which is the Student Internship Program of the Philippines (SIPP).

TABLE V LEVEL OF REALIZATION ON THE STUDENT INTERNSHIP PROGRAM AS REVEALED BY THE RESPONDENTS

\begin{tabular}{|c|c|c|c|c|}
\hline $\begin{array}{l}\text { Guidelines for } \\
\text { Student Interns } \\
\text { Coordinator/ } \\
\text { Adviser }\end{array}$ & Mode & Interpretation & (\%) & Rank \\
\hline $\begin{array}{l}\text { Inspect internship } \\
\text { venues and sites; }\end{array}$ & 3 & Realized & 53.19 & 1 \\
\hline $\begin{array}{l}\text { Screen and survey } \\
\text { understudy } \\
\text { assistants } \\
\text { occasionally }\end{array}$ & 3 & Realized & 53.19 & 1 \\
\hline $\begin{array}{l}\text { Counsel and help } \\
\text { understudy } \\
\text { assistants in settling } \\
\text { issues/issues } \\
\text { experienced }\end{array}$ & 3 & Realized & 48.94 & 2 \\
\hline $\begin{array}{l}\text { Approve the } \\
\text { aftereffect of the } \\
\text { temporary position } \\
\text { toward the finish of } \\
\text { the temporary job } \\
\text { time frame }\end{array}$ & 3 & Realized & 46.81 & 3 \\
\hline $\begin{array}{l}\text { Mentor or tutor } \\
\text { understudy } \\
\text { assistants } \\
\end{array}$ & 3 & Realized & 46.81 & 3 \\
\hline Aggregate Mode & 3 & Realized & & \\
\hline
\end{tabular}


Table V shows the data on assessing the level of Realization as perceived by the respondents from the Student Interns Coordinator/ Adviser guidelines.

It shows that indicators to coordinate with the Dean for the Internship orientation and seminar and Coach or mentor student interns got the lowest Mode and interpreted as Highly Realized.

Workshops are equipped for keeping the understudies refreshed with the advancements. Courses give the most recent data about the things which are occurring in science and innovation. Understudies cannot improve information from course readings alone; partaking in different workshops on most recent points is useful (Morgan, 2016).

Consulting and assisting student interns in resolving problems/ issues and validating the internship result at the end of the internship period also got the lowest Mode and were interpreted as Highly Realized.

As Gresham and Lopez (1996) indicated, Social legitimacy manages three essentials; however, profoundly complex inquiries are looked at by school therapists in the act of counsel every day. What should be changed, in what manner would it be advisable for it to be changed, and how can one know whether it was powerful? These issues are discussed, and explicit suggestions are made to think about social legitimacy in the schools' appraisal, plan, usage, and assessment of conference based mediations.

\section{CONCLUSION}

The internship program is intended to give understudies an occasion to supplement formal learning with handy information, aptitudes, and engaging perspectives and to pick up hands-on involvement with perceived Host Training Establishment (HTE ). To ensure the Realization of the Internship Program, the College of Business and Accountancy should develop a closely monitored system and be sustained from time to time based on each respective program's students' needs. Though the results concluded a Highly Realized interpretation, It does not guarantee that the system being used is being effective. It is based on a statistical approach in which the researcher has another perspective on a practical approach to getting the significance of this research study.

\section{REFERENCES}

[1] C.Allen, "Key Strategies for Converting Interns," Retrieved from https://bit.ly/300bVlp, 2013.

[2] CHED. CMO 104 s. 2017. "Revised Guidelines for Student Internship Program in the The Philippines," Retrieved from https://bit.ly/2XTsJJx,2017.

[3] H.T. Chen, "Theory-driven evaluation: Conceptual framework, application, and advancement,” Retrieved from https://bit.ly/2IcO0sP, 2012.

[4] Committee on Pediatric Workforce, S. O. " Prevention of Sexua Harassment in the Workplace and Educational Settings," Retrieved from https://bit.ly/2H69s10, 2000.
[5] R. Lozano, FM. Alemayehu, S. Ekwaro-Osire and HB. Endeshaw "Determining Probability of Importance of Features in a Sketch," ASME. ASME J. Risk Uncertainty Part B. 2017: Vol.3, No.4, Retrieved from https://bit.ly/3lVbZNp, 2017.

[6] DTI . "Joint Memorandum Circular No. 01, Series 2010, Guidelines in Implementing the Standards in Processing Business Permits and license in all Cities and Municipalities, "Retrieved from https://bit.ly/2FhmTuc, 2010.

[7] S. Donaldson, "Strategies and Applications: Program Theory-Driven Evaluation Science,” Hove, East Sussex BN3 2FA, New York: Routledge. Retrieved from https://bit.ly/2MVJBhX, 2012.

[8] Education State University, "Philippines - Educational System - an overview,” Retrieved from https://bit.ly/2Fgb6fD, 2019.

[9] P.G. Fishman, B. Nowell, and H.Yang, "Putting the system back into systems change: A framework for understanding and changing organizational and community systems," American Journal of Community Psychology, Vol.39, No.3-4, pp.197-215. Retrieved from https://bit.ly/2VR9fpy, 2007.

[10] C. Fuentealba , "The Role of Assessment in the student learning process," U.S. National Library of Medicine National Institute of Health, Vol. 38, No.2, pp.157-62. Retrieved from https://bit.ly/2VMQhjW.

[11] C. Funnell, and P.J.Rogers, "Purposeful Program Theory: Effective Use of Theories of Change and Logic Models," Retrieved from https://bit.ly/2XUN80W, 2011.

[12] F.M. Gresham, and M.F. Lopez, Social validation: A unifying concept for school-based consultation research and practice. School Psychology Quarterly, Vol.11, No.3, pp. pp.204-227.Retrieved from https://bit.ly/3lUVeBY, 1996.

[13] F. Kamau, "Enhancing Job Motivation to improve Employee Performance," Vaasan Ammattikorkeakoulu University of Applied Sciences. Retrieved from: https://bit.ly/2WMS2M3, 2015.

[14] M. Lewis, S.Kroeger, and M. Zender, "Defining Program-Based Student Learning Outcomes (SLOs) and Translating Them Into a Curricular Structure,” Retrieved from https://bit.ly/2CZZNan. 2009.

[15] S. Liew , T. Shadan, and E. Lim , Strategic and Tactical Approaches on University - Industry Collaboration,” Procedia - Social and Behavioral Sciences Journal, Vol. 56, 8 October 2012, pp. 405-409. Retrieved from https://bit.ly/3mYlTiG, 2012.

[16] R. Maini, S.M. Jack and J. Borghi, "How to and how not to develop a theory of change to evaluate a complex intervention: reflections on an experience in the Democratic Republic of Congo,” BMJ Global Health Journals,Vol.1, No. 3. Retrieved from https://bit.ly/3opghOG. 2017.

[17] M. Mead, "What is Systems Theory? Environment and Ecology," Retrieved from https://bit.ly/2IntVzx. 2019.

[18] S. Mikkonen, L. Pylväs, H. Rintala, P. Nokelainen and L. Postareff, "Guiding workplace learning in vocational education and training: A literature review," Empirical Research in Vocational Education and Training, Vol. 9, No.1. Retrieved from https://bit.ly/2LkGaB7, 2017.

[19] D. Miller, "Importance of School Monitoring And Evaluation Systems," Retrieved from https://bit.ly/2BKbxQ3. 2017.

[20] K. Morgan, What Are the Benefits of Attending Seminars? Retrieved from https://bit.ly/2AF34Ls, 2016.

[21] T. Repaso, "Revised Guidelines for Student Internship Program in the Philippines (SIPP) for all Programs- ChedMemorandum Order No. $104 \mathrm{~s}$. 2017. Retrieved from https://bit.ly/31HsJyu, 2019.

[22] R. Saunders, "Implementation of Monitoring and Process Evaluati," The United States of America: SAGE Publications, Inc. Retrieved fromhttps://bit.ly/2KXlf4C, 2015.

[23] R.R. Sims, "Reforming (transforming?) A Public Human Resource Management Agency: The Case of the Personnel Board of Jefferson County, Greenwood Publishing Group,” Retrieved from https: //bit.ly/ 3fy2uC5, 2010

[24] E. Siu, "Small Business Heroes, This Is Why You Should Consider Getting a Degree in Marketing,” Retrieved from https://bit.ly/2k1veJu, 2017.

25] J. Pachman, "The evidence base for pre-employment medical screening," Bulletin of the World Health Organization, Vol.87, No.7, pp.529-534. Retrieved from https://bit.ly/2LhFRXC,2009.

26] R.L. Purvis, T.J. Zagenczyk and G.E. McCray, "What is in it for me? Using expectancy theory and climate to explain stakeholder participation, its direction and intensity," International Journal of Project Management, Vol. 33, No.1, pp.3-14. Retrieved from https://bit.ly/39YbnE6, 2015.

27] K. Weaver, "4. Expectancy Theory - PSYCH 484: Work Attitudes and Job Motivation," Retrieved from https://bit.ly/2wYVWa7, 2

[28] J.W. Weiss, "What is the Theory of Change? The Center Theory of Change" Retrieved from https://bit.ly/2AItewn, 2019. 